\section{Rubel Viktoria, Rubel Vyacheslav}

\title{
ANALYSIS OF THE EFFICIENCY OF THE METHODS OF INTENSIFICATION UNDER THE SET CONDITIONS
}

The object of research is the well stimulation processes, namely acid treatments. The studies carried out are based on the influential acids on the productive formation, which is represented by limestone, on an increase in well production, a decrease in water cut, the duration of the effect, and additional production.

The main hypothesis of research is the assumption that the effectiveness of stimulation methods is determined by the change in flow rates and water cut of wells before and after the treatments. This method of evaluating the effectiveness allowes to determine the fundamental possibility and prospects of using one or another type of impact on the bottomhole formation zone (BFZ). Regression analysis to identify the influence of geological, physical and technological factors on the efficiency of stimulation in wells is considered. Equations are shown that describe the quantitative influence of each of the considered geological and technological factors on the efficiency of well treatments. The obtained equations make it possible to select the optimal conditions for well stimulation for the given conditions in order to achieve the planned efficiency.

The sequence of changes in the studied parameters characterizes the effectiveness of various types of impact on the BFZ. However, this method does not allow determining the quantitative effect of a specific geologicalphysical or technological factor on the efficiency of well stimulation. In the case of two-stage treatments on high-water-cut wells, the number of parameters on which the effectiveness of the entire measure may depend, increases several times. In this case, in order to identify the degree of influence of one factor or another on the efficiency of well treatment, it is possible to determine after carrying out multivariate statistical analysis and building mathematical models.

It was found that both the increase in production rate and the volume and pressure of acid injection play an important role in the treatment of carbonate rocks with hydrochloric acid. But the most important role is played by the degree of water cut. In this paper it was suggested to use a more complex stimulation method, which will simultaneously reduce the water cut and increase the well flow rate.

Keywords: hydrochloric acid treatment, hydrolyzed polyacrylonitrile-acid treatment, reservoir rock, fluid extraction intensification, water cut, Fisher's test, multiple regression.

Received date: 15.04 .2020

Accepted date: 08.06.2020

Published date: 31.10 .2020
Copyright (c) 2020, Rubel Viktoria, Rubel Vyacheslav This is an open access article under the CC BY license (http://creativecommons.org/licenses/by/4.0)

\section{Introduction}

One of the urgent problems in the oil and gas industry is to improve the efficiency of well operation and increase fluid production. Specific mining and geological conditions of occurrence of productive strata leave a significant imprint on the technological features of well operation, as well as the fact that the increase in water cut increases over time [1, 2]. Therefore, the use of traditional methods of stimulation is not always justified, because, firstly, it can cause irreversible changes in the productive reservoir. This leads to irreplaceable losses of hydrocarbons. And, secondly, a serious negative impact on the environment of the ecosystem [3, 4].

Having analyzed all these factors, set to solve such urgent tasks:

- to perform geological and industrial analysis of the field development and systematize the results of the application of technologies for intensifying fluid production;

- to experimentally substantiate new acidic compositions of reagents to increase hydrocarbon production.
The object of research is the well stimulation processes, namely acid treatments.

The aim of research is to determine if the chemical composition of acids will better affect the carbonate reservoir rock in difficult geological conditions.

\section{Methods of research}

The effectiveness of stimulation methods is determined by the change in the flow rate and water cut of the wells before and after the treatments. The necessary input for the calculations is in the fields. In this case, the assessment of the efficiency of the increase in oil production is reduced to determining the dependences of changes in the flow rate and water cut of wells after treatment, in comparison with the values of these parameters for treatment $[5,6]$. This method of evaluating the effectiveness makes it possible to determine the fundamental possibility and prospects of applying one or another type of impact on the BFZ. The sequence of changes in the studied parameters characterizing the effectiveness of 
various types of impact on the bottomhole formation zone (BFZ) can be traced in dynamics, for example, by the nature of water cut growth. However, this method does not allow determining the quantitative effect of a specific geological-physical or technological factor on the efficiency of well stimulation. In the case of two-stage treatments, for example, clay-acid treatment (CAT), at high-water wells, the number of parameters on which the effectiveness of the entire measure may depend increases several times. In this case, in order to identify the degree of influence of one factor or another on the efficiency of CAT wells, it can be determined after conducting multivariate statistical analysis and building mathematical models [7, 8].

For the statistical calculation, it was decided to use multivariate analysis. The research carried out is based on the application of the approaches described in $[9,10]$.

Based on the correlation analysis of the data, let's obtain the equations and correlation coefficients:

1. The dependence of the injection pressure of calcium chloride on the volume of hydrochloric acid:

$$
P_{\text {cacl } 2}=-0.7433+0.9768 V_{H C L}
$$

where $P_{\text {cacl2 }}$ - the injection pressure of calcium chloride; $V_{H C L}$ - the volume of hydrochloric acid. Correlation coefficient $r=0.909$. Fisher's coefficient $=90.66$, and $F_{c r}=161.4476$.

2. Dependence of the hydrochloric acid injection pressure on the volume of displacement water:

$$
V_{s . w}=4.785+0.4642 P_{H C L},
$$

where $V_{s . w}$ - the volume of squeezing water; $P_{H C L}-$ hydrochloric acid injection pressure. Correlation coefficient $r=0.9622$. Fisher's coefficient $=90.66$, and $F_{c r}=161.4476$.

3. Dependence of the influence of the well flow rate to treatment on the well flow rate after treatment:

$$
q_{b . o}=0.332+0.5711 q_{a . o},
$$

where $q_{b . o}$ - oil flow rate before treatment; $q_{a . o}-$ oil production rate after treatment. Correlation coefficient $r=0.95$. Fisher's coefficient $=160.02$, and $F_{c r}=161.4476$.

4. Dependence of the production water cut for treatment on additional oil production:

$$
W_{b, o}=44.29+0.115 \Delta Q,
$$

where $W_{b . o}$ - the degree of the production water cut before treatment; $Q$ - additional oil production. Correlation coefficient $r=0.98$. Fisher's coefficient $=232.23$, and $F_{c r}=240.54$.

5 . Dependence of the production water cut before treatment on product water cut after treatment:

$$
W_{b . o}=-75.0382+1.685 W_{a . o},
$$

where $W_{b . o}$ - the degree of the production water cut before treatment; $W_{a . o}$ - the degree of production water cut after treatment. Correlation coefficient $r=0.98$. Fisher's coefficient $=235.4748$, and $F_{c r}=240.54$.

6. Dependence of the effect of additional oil production on the water cut after treatment:

$$
\Delta Q=12.3021+4.921 W_{b . o}
$$

where $\Delta Q$ - additional oil production; $W_{a . o}-$ degree of water cut after treatment. Correlation coefficient $r=0.99$. Fisher's coefficient $=224.6735$, and $F_{c r}=230.16$.

7. Dependence of the effect of oil flow rate on treatment on the water cut ratio in the product after treatment and before treatment:

$$
q_{b . o}=-0.8789+3.4982 \frac{W_{b . o}}{W_{a . o}},
$$

where $q_{b . o}$ - oil production rate before treatment; $W_{b . o} / W_{a . o}$ degree of water cut reduction. Correlation coefficient $r=0.91$. Fisher's coefficient $=88.06695$, and $F_{c r}=161.45$.

\section{Research results and discussion}

As a result of the carried out multivariate regression analysis [11] of the influence of geological, physical and technological factors affecting the CAT efficiency, it was revealed that the efficiency of CAT depends on two groups of factors. Firstly, it depends on the quality of blocking water supply channels to the watered fractured part of the formation. Secondly, the quality of the hydrochloric acid impact on the pore oil-saturated part of the reservoir. However, the effectiveness of hydrochloric acid action largely depends on the full-fledged implementation of waterproofing works with reliable blockage of water supply channels, and the insulating material must have stable strength properties to prevent acid from entering water supply channels:

$$
\Delta Q=-135.343+4.88 T_{e f}+0.5 \frac{W_{b . o}}{W_{a . o}},
$$

where $\Delta Q$ - additional oil production. Correlation coefficient $r=0.91$. Fisher's criterion $=90.809$.

Analysis of the obtained equations shows that the CAT efficiency is more likely to be described by additional oil production from the measure $(\Delta Q)$. Intermediate efficiency can be characterized by the duration of the effect $\left(T_{e f}\right)$, and the CAT success at the time of the measure in terms of the increase in oil production rate and the degree of water cut reduction $\left(W_{b . o} / W_{a . o}\right)$ :

$$
\Delta Q=99.944+42.46 V_{h}+5.6 P_{h},
$$

where $V_{h}$ - the hydrolyzed polyacrylonitrile volume; $P_{h}-$ the hydrolyzed polyacrylonitrile injection pressure. Correlation coefficient $r=0.904$. Fisher's criterion $=40.677$.

It can be seen from equation (9) that the maximum positive effect on additional oil production from CAT wells $(\Delta Q)$ has the hydrolyzed polyacrylonitrile volume $\left(V_{h}\right)$, injection pressure $\left(P_{h}\right)$ and the volume of squeezing water injection $\left(V_{w}\right)$. The greatest negative impact is exerted by the volume of calcium chloride $\left(V_{c . c .}\right)$ and the well production rate for oil:

$$
\begin{aligned}
& \frac{q_{b . o}}{q_{a . o}}=0.467+0.079 V_{h}-0.021 P_{h} ; \\
& \frac{q_{b . o}}{q_{a . o}}=0.267-0.0026 V_{c . c}+0.068 P_{c . c} .
\end{aligned}
$$

From the obtained equations (10) and (11) it can be seen that the increase in oil production rate $\left(q_{b . o} / q_{a . o}\right)$ 
and the degree of water cut decrease $\left(W_{b . o} / W_{a . o}\right)$ depend more on:

- calcium chloride volume $\left(V_{c . c}\right)$;

- hydrolyzed polyacrylonitrile volume $\left(V_{h}\right)$;

- volume and pressure of hydrochloric acid injection ( $V_{h . a}$ and $\left.P_{h . a}\right)$;

- volume and pressure of injection of squeezing water $\left(V_{w}\right.$ and $\left.P_{w}\right)$;

- wells production rate for oil before treatment $\left(q_{b . o}\right)$.

The expected oil production rate of the well after CAT is higher, and the water cut is lower when a small amount of acid is pumped at low pressure. Obviously, when pumping large volumes of acid at high pressure, the acid can be forced into the water cut of highly permeable interlayers and lead to an increase in water cut. The larger the volume of injected hydrolyzed polyacrylonitrile $\left(V_{h}\right)$, the better the water cut interlayers overlap, which reduces the water cut and increases the oil production rate of the well.

When conducting CAT in the process of filtration, a previously non-working formation thickness is mined, and the larger it is, the more effect:

$$
T_{e f}=-14.31-8.3994 \frac{W_{b . o}}{W_{a . o}}+200.067 \frac{q_{b . o}}{q_{a . o}} .
$$

Correlation coefficient $r=0.8$. Fisher's criterion $=14.43$.

From equation (12) it can be seen that the ratio of the increase in oil production rate $\left(q_{b . o} / q_{a . o}\right)$ and the degree of water cut decrease $\left(W_{b . o} / W_{a . o}\right)$ has the maximum positive effect on the duration of the effect.

The obtained equations and dependencies make it possible to select the optimal conditions for conducting CAT wells for the given conditions in order to achieve the planned efficiency.

\section{Conclusions}

The mathematical models and dependencies obtained in the course of the study make it possible to most fully reveal the influence of geological, physical and technological parameters of CAT on the efficiency of well treatments. As independent variables, 14 geological and technological parameters of the CAT were used, as the response functions - 6 main criteria for the CAT efficiency of the wells. The interpretation of the results of multivariate regression analysis was carried out and the main groups of factors that most of all affect the results of the CAT efficiency were identified.
The multiple correlation coefficients for the equations are $0.904-0.99$. This means that the constructed regression explains the reliability of the forecast results by $90.4 \%$ and $99 \%$.

The obtained regression equations can be used to predict the effectiveness of well stimulation under specified conditions.

\section{References}

1. Antipin, Iu. V., Lysenkov, A. B., Karpov, A. A., Tukhteev, P. M. Ibraev, P. A., Stenechkin, Iu. N. (2007). Intensifikatsiia dobychi nefti iz karbonatnykh plastov. Neftianoe khoziaistvo, 5, 96-98.

2. Verderevskii, Iu. L, Arefev, Iu. N., Chaganov, M. S., Asmolovskii, B. C., Saifutdinov, F. Kh. (2000). Uvelichenie produktivnosti skvazhin $\mathrm{v}$ karbonatnykh kollektorakh sostavami na osnove solianoi kisloty. Neftianoe khoziaistvo, 1, 39-40.

3. Galliamov, I. M., Vakhitov, T. M., Shafikova, E. A., Apkarimova, G. I., Sudakov, M. S., Samigullin, I. F. et. al. (2008). K probleme primeniaemosti polimernykh sostavov v usloviiakh nizkikh temperatur. Novoe v geologii i razrabotke neftianykh mestorozhdenii Bashkortostana. Ufa: Izd-vo Bashgeproekt, 120, 221-225.

4. Ivanov, S. I. (2006). Intensifikatsiia pritoka nefti $i$ gaza $k$ skvazhinam. Moscow: OOO Nedra-Biznestsentr, 565.

5. Gmurman, V. E. (2004). Rukovodstvo $k$ resheniiu zadach po teorii veroiatnostei i matematicheskoi statistike. Moscow: Vysshaia shkola, 390.

6. Efimova, M. R., Petrova, E. V., Rumiantsev, V. N. (2006). Obschaia teoriia statistiki. Moscow: INFRA-M, 416.

7. Kolganov, V. I. (2003). Vliianie treschinovatosti karbonatnykh kollektorov na pokazateli ikh razrabotki pri zavodnenii. Neftianoe khaziaistvo, 11, 51-54.

8. Lysenkov, A. B., Antipin, Iu. V., Stenichkin, Iu. N. (2009). Intensifikatsiia pritoka nefti iz gidrofobizirovannykh karbonatnykh kollektorov s vysokoi obvodnennostiu. Neftianoe khoziaistvo, 6, 36-39.

9. Mischenko, I. T., Sagdiev, R. F. (2003). Ustanovlenie rezhima ekspluatatsii dobyvaiuschei skvazhiny pri zaboinom davlenii nizhe davleniia nasyscheniia. Neftianoe khoziaistvo, 4, 104-106.

10. Orlov, G. A., Musabirov, M. Kh., Denisov, D. G. (2003). Sistemnoe primenenie tekhnologii kislotnoi stimuliatsii skvazhin i povysheniia nefteotdachi plastov $\mathrm{v}$ karbonatnykh kollektorakh. Interval, 9, 27-31.

11. Ross, S. (2017). Introductory statistics. London: Elsevier. Available at: https://www.academia.edu/7196922/Ross S Introductory_statistics

Rubel Viktoria, PhD, Associate Professor, Department of Oil and Gas Engineering and Technologies, National University «Yuri Kondratyuk Poltava Polytechnic», Ukraine, ORCID: http://orcid.org/ 0000-0002-6053-9337, e-mail: veca.rubel@gmail.com

Rubel Vyacheslav, Postgraduate Student, Department of Oil and Gas Engineering and Technologies, National University «Yuri Kondratyuk Poltava Polytechnic», Ukraine, ORCID: http://orcid.org/0000-00025418-5595, e-mail: stanikslav1985@gmail.com 